western Mediterranean Sea. The effect of DMV infection on the health and conservation of the threatened Eurasian otter populations warrants further investigation.

\section{Acknowledgments}

We thank Antonio Lo Polito, Maria Luigia Prencipe, and Fabio Gisoldo for their valuable technical support. We also thank Gabriella Di Francesco, Alessio Lorusso, Daniela Malatesta, and Guendalina Zaccaria for their valuable support in performing histopathological, immunohistochemical, and biomolecular analyses as well as for their greatly appreciated contribution to fruitful and insightful discussions on the data reported in the manuscript.

\section{About the Author}

Dr. Padalino works at the Virology Department of Istituto Zooprofilattico Sperimentale della Puglia e della Basilicata, Foggia, Italy, where she is in charge of the Molecular Biology and Cell Culture Laboratory. Her research is mainly focused on the molecular diagnosis and epidemiologic surveillance of viral infectious diseases in domestic and wild animals.

\section{References}

1. Van Bressem MF, Duignan PJ, Banyard A, Barbieri M, Colegrove KM, De Guise S, et al. Cetacean morbillivirus: current knowledge and future directions. Viruses. 2014;6:5145-81. http://dx.doi.org/10.3390/v6125145

2. Mazzariol S, Centelleghe C, Beffagna G, Povinelli M, Terracciano G, Cocumelli C, et al. Mediterranean fin whales (Balaenoptera physalus) threatened by dolphin morbillivirus. Emerg Infect Dis. 2016;22:302-5. http://dx.doi.org/10.3201/eid2202.150882

3. Mazzariol S, Centelleghe C, Di Provvido A, Di Renzo L, Cardeti G, Cersini A, et al. Dolphin morbillivirus associated with a mass stranding of sperm whales, Italy. Emerg Infect Dis. 2017;23: 144-6. http://dx.doi.org/10.3201/eid2301.160239

4. Frisk AL, König M, Moritz A, Baumgärtner W. Detection of canine distemper virus nucleoprotein RNA by reverse transcription-PCR using serum, whole blood, and cerebrospinal fluid from dogs with distemper. J Clin Microbiol. 1999;37:3634-43.

5. Centelleghe C, Beffagna G, Zanetti R, Zappulli V, Di Guardo G, Mazzariol S. Molecular analysis of dolphin morbillivirus: a new sensitive detection method based on nested RT-PCR. J Virol Methods. 2016;235:85-91. http://dx.doi.org/10.1016/ j.jviromet.2016.05.005

6. Verna F, Giorda F, Miceli I, Rizzo G, Pautasso A, Romano A, et al. Detection of morbillivirus infection by RT-PCR RFLP analysis in cetaceans and carnivores. J Virol Methods. 2017; 247:22-7. http://dx.doi.org/10.1016/j.jviromet.2017.05.009

7. Mos L, Ross PS, McIntosh D, Raverty S. Canine distemper virus in river otters in British Columbia as an emergent risk for coastal pinnipeds. Vet Rec. 2003;152:237-9. http://dx.doi.org/10.1136/ vr.152.8.237

8. Jo WK, Osterhaus AD, Ludlow M. Transmission of morbilliviruses within and among marine mammal species. Curr Opin Virol. 2018;28:133-41. http://dx.doi.org/10.1016/j.coviro.2017.12.005

9. Mazzariol S, Peletto S, Mondin A, Centelleghe C, Di Guardo G, Di Francesco CE, et al. Dolphin morbillivirus infection in a captive harbor seal (Phoca vitulina). J Clin Microbiol. 2013;51:708-11. http://dx.doi.org/10.1128/JCM.02710-12

10. Kondratov IG, Denikina NN, Belikov SI, Durymanova AA, Ustinova EN, Shestopalov AM. Mollusks as a natural reservoir of morbilliviruses. Dokl Biol Sci. 2003;389:154-6. http://dx.doi.org/10.1023/A:1023435312334

Address for correspondence: Giovanni Di Guardo, University of Teramo, Faculty of Veterinary Medicine, Località Piano d'Accio, 64100, Teramo, Italy; email: gdiguardo@unite.it

\title{
Little Evidence of Zika Virus Infection in Wild Long-Tailed Macaques, Peninsular Malaysia
}

\section{Chong Long Chua, Yoke Fun Chan, Eva S.G. Soh Andu, Jeffrine J. Rovie-Ryan, Frankie Thomas Sitam, Khebir Verasahib, I-Ching Sam}

Author affiliations: University of Malaya, Kuala Lumpur, Malaysia (C.L. Chua, Y.F. Chan, E.S.G. Soh Andu, I-C. Sam); Department of Wildlife and National Parks Peninsular Malaysia, Kuala Lumpur (J.J. Rovie-Ryan, F.T. Sitam); National Public Health Laboratory, Sungai Buloh, Malaysia (K. Verasahib)

DOI: https://doi.org/10.3201/eid2502.180258

We tested a sample of 234 wild long-tailed macaques (Macaca fascicularis) trapped in Peninsular Malaysia in 2009, 2010, and 2016 for Zika virus RNA and antibodies. None were positive for RNA, and only $1.3 \%$ were seropositive for neutralizing antibodies. Long-tailed macaques are unlikely to be reservoirs for Zika virus in Malaysia.

\section{Z} ika virus, first isolated from a rhesus macaque (Macaca mulatta) in the Zika Forest in Uganda, reemerged in the Pacific Islands and Americas in 2015 and caused unprecedented outbreaks associated with serious congenital syndromes (1). The role of animal reservoirs for Zika virus is unclear, although in Africa, nonhuman primates (NHPs) are suspected to be involved in maintaining a sylvatic cycle, as they are for 2 other flaviviruses (yellow fever and dengue viruses) also transmitted by Aedes mosquitoes. The presence of a sylvatic cycle for Zika virus in Africa is supported by a seroprevalence of $0 \%-16 \%$ in African green monkeys (Chlorocebus sabaeus) and vervet monkeys (Chlorocebus 
pygerythrus) (2). However, even less is known about the potential role of NHPs in sylvatic cycles in Asia.

In Malaysia, Zika virus seropositivity has been reported in residents $(3,4)$, monkeys (5), and orangutans (4), suggesting endemicity. Continual encroachment of human settlements into monkey habitats potentially increases human risk for exposure to monkey-associated zoonotic pathogens. We therefore evaluated Zika virus prevalence in long-tailed macaques ( $M$. fascicularis), the most common macaque in Peninsular Malaysia, which is also widespread throughout Southeast Asia.

Staff of the Department of Wildlife and National Parks Peninsular Malaysia (also called Jabatan Perlindungan Hidupan Liar dan Taman Negara Semenanjung Malaysia [PERHILITAN]) traps monkeys foraging in humanpopulated areas and relocates them to deep forest areas (6). As part of PERHILITAN's Wildlife Disease Surveillance Program, serum samples were collected from 234 long-tailed macaques trapped at $>30$ sites throughout Malaysia in the states of Selangor, Negeri Sembilan, Perak, Pahang, Penang, and Johor (approval no. PERHILITAN JPHL\&TN(IP): $100-34 / 1.24$ ) and stored at $-80^{\circ} \mathrm{C}$. This collection comprised 145 samples acquired during October-November 2009 and October 2010 (6) and 89 acquired in March and August 2016, coinciding with the Zika virus global epidemics.

After extracting viral RNA from samples with a QIAamp Viral RNA Mini Kit (QIAGEN, https://www. qiagen.com), we tested samples with sufficient serum volume $(\mathrm{n}=228)$ for Zika virus envelope gene by real-time PCR (7); none were positive. We tested all 234 samples for Zika virus neutralizing antibody by $50 \%$ plaque reduction neutralization test $\left(\mathrm{PRNT}_{50}\right)$ on Vero cells (Appendix, https://wwwnc.cdc.gov/EID/article/25/2/18-0258-App1. pdf). In total, 6 (2.6\%) samples had screening Zika virus $\mathrm{PRNT}_{50}$ titers $\geq 20$ (Table); we confirmed results with a $50 \%$
Zika virus focus reduction neutralization test $\left(\mathrm{FRNT}_{50}\right)$, and samples had titers identical to or within 1 dilution of the $\mathrm{PRNT}_{50}$ titer.

Because flavivirus antibodies are known to cross-react, these 6 samples were further examined for antibodies specific to the major known circulating flaviviruses in Malaysia, dengue virus serotypes 1 (DENV-1) and 2 (DENV-2), by $\mathrm{FRNT}_{50}$. A sample was considered to have evidence of Zika virus neutralizing antibody if the Zika virus PRNT $_{50}$ titer was $\geq 20$ and DENV- 1 and DENV-2 FRNT ${ }_{50}$ titers were $<20$ ( 2 samples) or if the Zika virus $\mathrm{PRNT}_{50}$ titer was $\geq 20$ and 4-fold greater than the DENV-1 and DENV-2 FRNT titers (1 sample). Only 3 of 6 samples fulfilled these criteria; the remaining 3 contained detectable Zika virus, DENV-1, and DENV-2 antibodies, indicating past flavivirus infection of an indeterminate type. Thus, $3(1.3 \%)$ of 234 samples were Zika virus seropositive, although we did not test for other flaviviruses.

The 3 Zika virus-seropositive monkeys were captured $35 \mathrm{~km}$ away (in Bukit Serendah, Selangor), $77 \mathrm{~km}$ away (in Kuala Lipis, Pahang), and $164 \mathrm{~km}$ away (in Manong, Perak) from Bentong (Pahang), where Zika virus was first isolated outside of Africa in 1966 (5). Of note, 5 of 6 samples with detectable Zika virus antibodies were collected in 2016, when human Zika virus cases were occurring in Malaysia and neighboring Thailand and Singapore. The rate of Zika virus antibody detection was higher in the 2016 collection $(5.6 \%, 5 / 89)$ than the $2009-2010$ collection $(0.7 \%$, $1 / 145 ; p=0.031$ by Fisher exact test).

Our results indicate that wild long-tailed macaques in Peninsular Malaysia are exposed to Zika virus but at low levels, without evidence of viremia. This finding suggests that long-tailed macaques are unlikely involved in maintaining Zika virus sylvatic cycles in Malaysia, although the long-term dynamics of Zika virus antibodies and infection (including shedding) in macaques is unknown. This in-

Table. Zika virus, DENV-1, and DENV-2 neutralization titers of serum samples collected from long-tailed macaques in Peninsular Malaysia, 2009, 2010, and 2016*

\begin{tabular}{|c|c|c|c|c|c|c|c|}
\hline \multirow[b]{2}{*}{$\begin{array}{l}\text { Sample collection period } \\
\text { and size }\end{array}$} & \multirow[b]{2}{*}{$\begin{array}{l}\text { No. } \\
\text { samplest }\end{array}$} & \multirow[b]{2}{*}{$\begin{array}{l}\text { Macaque sex and } \\
\text { age group, ID no. }\end{array}$} & \multirow[b]{2}{*}{$\begin{array}{c}\text { Town/City, } \\
\text { state, coordinates }\end{array}$} & \multicolumn{4}{|c|}{ Neutralization titers } \\
\hline & & & & $\begin{array}{l}\text { Zika virus } \\
\text { PRNT }_{50}\end{array}$ & $\begin{array}{c}\text { Zika virus } \\
\text { FRNT }_{50}\end{array}$ & $\begin{array}{l}\text { DENV-1 } \\
\text { FRNT }_{50}\end{array}$ & $\begin{array}{l}\text { DENV-2 } \\
\text { FRNT }_{50}\end{array}$ \\
\hline $\begin{array}{l}\text { October-November } 2009 \\
\text { and October } 2010, \mathrm{n}=145\end{array}$ & 1 & $\begin{array}{l}\text { Male adult, } \\
\text { ZMW604 }\end{array}$ & $\begin{array}{c}\text { Bukit Serendah, Selangor, } \\
3.36^{\circ} \mathrm{N}, 101.60^{\circ} \mathrm{E}\end{array}$ & 640 & 640 & $<20$ & $<20$ \\
\hline \multirow[t]{5}{*}{$\begin{array}{l}\text { March and August 2016, } \\
\mathrm{n}=89\end{array}$} & 5 & $\begin{array}{l}\text { Female juvenile, } \\
\text { PMW804 }\end{array}$ & $\begin{array}{c}\text { Manong, Perak, } 4.61^{\circ} \mathrm{N} \\
100.90^{\circ} \mathrm{E}\end{array}$ & 40 & 20 & $<20$ & $<20$ \\
\hline & & $\begin{array}{l}\text { Female adult, } \\
\text { WDSP/16/009 }\end{array}$ & $\begin{array}{c}\text { Kuala Lipis, Pahang, } \\
4.18^{\circ} \mathrm{N}, 102.05^{\circ} \mathrm{E}\end{array}$ & 80 & 80 & $<20$ & 20 \\
\hline & & $\begin{array}{c}\text { Male adult, } \\
\text { WDSP/16/006 }\end{array}$ & $\begin{array}{c}\text { Kuala Lipis, Pahang, } \\
4.18^{\circ} \mathrm{N}, 102.05^{\circ} \mathrm{E}\end{array}$ & 80 & 80 & 640 & 160 \\
\hline & & $\begin{array}{c}\text { Male adult, } \\
\text { WDSP/16/012 }\end{array}$ & $\begin{array}{c}\text { Kuala Lipis, Pahang, } \\
4.18^{\circ} \mathrm{N}, 102.05^{\circ} \mathrm{E}\end{array}$ & 40 & 40 & 20 & 40 \\
\hline & & $\begin{array}{c}\text { Male adult, } \\
\text { WDSP/16/086 }\end{array}$ & $\begin{array}{l}\text { Batu Pahat, Johor, } 1.85^{\circ} \mathrm{N}, \\
102.94^{\circ} \mathrm{E}\end{array}$ & 40 & 20 & 40 & 20 \\
\hline
\end{tabular}

*DENV-1, dengue virus serotype 1; DENV-2, dengue virus serotype 2; FRNT $50,50 \%$ focus reduction neutralization test; ID, identification; PRNT $50,50 \%$ plaque reduction neutralization test.

†Number of samples from the first batch $(n=234)$ that were positive by Zika virus PRNT 50 and further tested by FRNT 50 . 
formation is arguably needed before an animal can be designated a reservoir (8). Despite intense Zika outbreaks in humans, no active Zika virus infection and a low seroprevalence $(2.9 \%)$ with low antibody titers was found in various NHP species in Brazil, suggesting that New World NHPs are unlikely to sustain sylvatic transmission cycles (9). Antibody responses after flavivirus infection are broadly cross-reactive and cross-neutralizing in the first few months after infection (10), but the effects against heterologous flaviviruses are poorly understood in wild macaques. Also, the circulation of Zika virus in macaques could be affected by the sylvatic cycles of other endemic flaviviruses. In conclusion, the low seroprevalence of Zika virus antibodies in long-tailed macaques reinforces the need to study other NHPs and mammals as reservoirs in Malaysia to elucidate Zika virus transmission and emergence.

\section{Acknowledgments}

We thank the outbreak response team of the Wildlife Disease Surveillance Program, PERHILITAN, for collecting monkey samples.

This study was supported by a Malaysia One Health University Network research grant and the US Agency for International Development.

\section{About the Author}

Dr. Chua is a postdoctoral research fellow at University of Malaya. His primary interest is host antibody responses to arbovirus infection.

\section{References}

1. Dick GW, Kitchen SF, Haddow AJ. Zika virus. I. Isolations and serological specificity. Trans R Soc Trop Med Hyg. 1952;46:50920. http://dx.doi.org/10.1016/0035-9203(52)90042-4

2. Buechler CR, Bailey AL, Weiler AM, Barry GL, Breitbach ME, Stewart LM, et al. Seroprevalence of Zika virus in wild African green monkeys and baboons. mSphere. 2017;2:e00392-16. http://dx.doi.org/10.1128/mSphere.00392-16

3. Smithburn KC. Neutralizing antibodies against arthropod-borne viruses in the sera of long-time residents of Malaya and Borneo. Am J Hyg. 1954;59:157-63.

4. Wolfe ND, Kilbourn AM, Karesh WB, Rahman HA, Bosi EJ, Cropp BC, et al. Sylvatic transmission of arboviruses among Bornean orangutans. Am J Trop Med Hyg. 2001;64:310-6. http://dx.doi.org/10.4269/ajtmh.2001.64.310

5. Marchette NJ, Garcia R, Rudnick A. Isolation of Zika virus from Aedes aegypti mosquitoes in Malaysia. Am J Trop Med Hyg. 1969;18:411-5. http://dx.doi.org/10.4269/ajtmh.1969.18.411

6. Sam IC, Chua CL, Rovie-Ryan JJ, Fu JY, Tong C, Sitam FT, et al. Chikungunya virus in macaques, Malaysia. Emerg Infect Dis. 2015;21:1683-5. http://dx.doi.org/10.3201/eid2109.150439

7. Lanciotti RS, Kosoy OL, Laven JJ, Velez JO, Lambert AJ, Johnson AJ, et al. Genetic and serologic properties of Zika virus associated with an epidemic, Yap State, Micronesia, 2007. Emerg Infect Dis. 2008;14:1232-9. http://dx.doi.org/10.3201/ eid1408.080287
8. Kuno G, Mackenzie JS, Junglen S, Hubálek Z, Plyusnin A, Gubler DJ. Vertebrate reservoirs of arboviruses: myth, synonym of amplifier, or reality? Viruses. 2017;9:185. http://dx.doi.org/ 10.3390/v9070185

9. Moreira-Soto A, Carneiro IO, Fischer C, Feldmann M, Kümmerer BM, Silva NS, et al. Limited evidence for infection of urban and peri-urban nonhuman primates with Zika and chikungunya viruses in Brazil. mSphere. 2018;3:e0523-17. http://dx.doi.org/10.1128/mSphere.00523-17

10. Collins MH, McGowan E, Jadi R, Young E, Lopez CA, Baric RS, et al. Lack of durable cross-neutralizing antibodies against Zika virus from dengue virus infection. Emerg Infect Dis. 2017; 23:773-81. http://dx.doi.org/10.3201/eid2305.161630

Address for correspondence: I-Ching Sam, University of Malaya, Department of Medical Microbiology, Faculty of Medicine, Kuala Lumpur 50603, Malaysia; email: jicsam@ummc.edu.my

\section{Severe Fever with Thrombocytopenia Syndrome Virus in Dogs, South Korea}

\author{
Jun-Gu Kang, Yoon-Kyoung Cho, Young-Sun Jo, \\ Jeong-Byoung Chae, Young-Hoon Joo, \\ Kyoung-Wan Park, Joon-Seok Chae
}

Author affiliations: Seoul National University, Seoul, South Korea (J.-G. Kang, Y.-K. Cho, Y.-S. Jo, J.-B. Chae, J.-S. Chae); Military

Working Dog Training Center of the Republic of Korea Army, Chuncheon, South Korea (Y.-H. Joo, K.-W. Park)

DOI: https://doi.org/10.3201/eid2502.180859

Of 103 serum samples collected from dogs in South Korea, $3(2.9 \%)$ were positive for severe fever with thrombocytopenia syndrome virus (SFTSV) and 22 (21.4\%) were positive for antibodies against SFTSV. A dog-derived isolate of SFTSV clustered with many South Korea SFTSV strains in the Japanese clade.

Qevere fever with thrombocytopenia syndrome virus (SFTSV), a new tickborne phlebovirus of the Phenuiviridae family (previously Bunyaviridae), causes severe fever with thrombocytopenia syndrome (SFTS) in China, Japan, and the Republic of Korea (South Korea) (1). After identification of the first human case of SFTS in South Korea in 2013 (1), 335 cases (73 deaths; case-fatality rate $21.8 \%$ ) were reported during 2013-2016 (2). 